\title{
“Empurrador de canoa não ganha nada não". Os vareiros do rio Grajaú e a circulação de mercadorias, pessoas e sonhos
}

DOSSIER RIOS E CIDADES

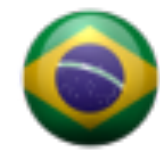

\section{Alan Kardec Gomes Pachêco Filho}

Doutor em História Social pela UFF. Professor Adjunto a Universidade Estadual do Maranhão, dos Programas de Pós-Graduação em História, Ensino e Narrativa e Desenvolvimento Social Regional. Chefe da Divisão de Editoração da mesma Universidade. São Luís [MA] Brasil. <alankardecpacheco@uol.com.br>.

\section{Resumo}

Reflete-se sobre o rio Grajaú, sua navegação e importância para a circulação de pessoas e mercadorias no Maranhão a partir de fragmentos de memória dos vareiros, 0 rio Grajaú ainda que de difícil navegação, tornou-se o caminho para o norte e corredor natural de exportação e importação de todo o centro sul e sertão maranhense, expandindo a zona de comércio da região até o norte de Goiás e o sul do Pará. Com o aparecimento de caminhões, a partir de 1950, utilizados para o transporte de mercadorias na região, houve uma tendência da navegação fluvial diminuir seu ritmo, principalmente no verão, quando o rio deixou de ser navegado por grandes embarcações. As águas do rio Grajaú não transportaram somente produtos. Como agente de ligação, o rio carregou um dos principais personagens dessa circulação, os vareiros. Esses trabalhadores do rio, além de empurrarem embarcações com varas, cheias de mercadorias, ora a favor ora contra a correnteza do rio, compartilharam experiências em dois ambientes muito distintos: o litoral e o sertão.

\section{Palavras-chave}

rio Grajaú, navegação, circulação, vareiro, memória.

\section{"Canoe pusher get nothing": The sailboat of Grajaú River and the movement of goods, people and dreams}

\begin{abstract}
On the river named Grajaú, its navigation and importance to the movement of people and goods in Maranhão from fragments of vareiros memory. The Grajaú river though difficult to navigate, it has become the way to the north and natural corridor to export and import of the whole center and hinterland south of Maranhão, expanding trade area in the region to the north of Goiás and south of Pará. With the emergence of trucks, since 1950, used to transport goods in the region, there was a trend of decrease waterway Navigation, especially in the summer, when the river stopped be navigated by large ships. The waters of the Grajaú not only transported products. As a connection, the river carried one of the main characters of this movement, the vareiros. These workers of the river, push ships with sticks, full of goods, against the current of the river, shared experiences in two very different environments: the coast and the hinterland.
\end{abstract}

\section{Keywords}

Grajaú river; navegation, moviment, vareiro, memory. 


\section{Introdução}

Nesse artigo recupero fragmentos das experiências dos trabalhadores do rio, Grajaú relacionandoas às dinâmicas da navegação. Parto da compreensão braudeliana de que o melhor documento sobre o passado do rio (que para Braudel era o mar) é ele próprio, tal como cada um o pode ver e amar. Assim, utilizo a história oral como método investigativo para estudar o espaço líquido do rio Grajaú com todos os encantos e perigos de uma novidade (BRAUDEL, 1983, p. 21), não há obras históricas sobre o estudo dos rios maranhenses que pudesse me auxiliar.

As entrevistas que fiz sobre a navegação no rio Grajaú, com pilotos de barcos, ex-pilotos, práticos, carpinteiros navais, ferreiros, proprietários de canoas, filhos de proprietários, regatões, passageiros, "contadores de história", vareiros brancos, negros e, principalmente vareiros índios, permitiram-me conhecer melhor os meandros da navegação do rio Grajaú em direção a Vitória do Mearim, na baixada maranhense. Essas memórias testemunharam e viveram a navegação no rio Grajaú. Esses relatos de experiências contribuíram de forma significativa para a elaboração desse capítulo.

Contudo, encontro conforto nas seguintes palavras: "Ninguém ignora que um interesse confessado e elucidado oferece um abrigo mais seguro do que vagos projetos de objetividade." (NORA, 1987, p.10). Confesso: fiz uma ego-história. Fui historiador de mim.

\section{A cidade e ses trabalhadores do rio}

Em Grajaú, o local onde as lanchas, as canoas, os batelões ficam ancorados aguardando nova viagem para Vitória do Mearim chama-se Portos das Pedras, fica aproximadamente uns trezentos metros abaixo do Porto Grande, outrora o principal da cidade. Fèbvre (2000, p. 9-10), disse que os rios têm várias histórias que podem ser contadas a partir do local de onde estamos para observá-lo. Pode ser do meio, de suas margens, do seu início, de sua foz ou de dentro de uma embarcação cuja propulsão pode ser a motor ou a tração humana, impulsionada por varas ou remos. Esse texto está diretamente relacionado com o cotidiano desses trabalhadores quando embarcados ou não. Não vou fixar o tempo de duração de uma viagem, elas variavam entre sessenta e cinco e noventa dias, os viajantes e as mercadorias embarcadas ficavam a mercê do rio. Só havia certeza do dia da partida, a chegada era sempre prevista para o mês subsequente.

As técnicas de navegação evoluíram sem dúvida, mas a segurança das embarcações utilizadas nessas viagens não se tornou mais confiáveis ou mais cômodas. Essas continuaram tão perigosas quanto a inicial da "conquista" ou as posteriores que consolidaram o assenhoramento da região. Se as viagens, no início do século XIX, pelo rio Grajaú, significaram a expansão da conquista, no final da mesma época e em meados do século XX, o rio já transformado em caminho, possibilitou condições para aqueles que em busca de riquezas materiais ou da própria sobrevivência se estabelecessem em seu entorno e pudessem dar continuidade a suas vidas.

Os trabalhadores do rio ou dos rios foram identificados por vários nomes: moços, moços de barca ou remeiros. Assim foram denominados no rio São Francisco; para o mesmo rio encontramos uma única referência a vareiro, feita por Thomaz Garcez Paranhos Montenegro (1875 apud NEVES, 1998, p. 196). No rio Tocantins, barqueiro do Tocantins. Gribaniers, na região de Amiens, Abbeville e Saint-Valéry, no rio Somme, na França (BRAUDEL, 1998, p. 315). Nos rios Parnaíba e Grajaú, Vareiro. Todos esses trabalhadores, nessas diferentes e distantes regiões, normalmente eram pouco considerados. Em França, Braudel $(1998$, p. 316) não especifica a cor da pele, entretanto diz que eram tratados como maus elementos, pois mantinham verdadeiras guerras com os mercadores, por elevarem constantemente o preço dos fretes. No Brasil esses trabalhadores dos rios sempre foram considerados pessoas de categoria social inferior, eram negros, mestiços ou homens brancos, livres e pobres. Na região por nós estudada, o rio Grajaú, houve uma relevante presença de índios, isso é facilmente explicado pela quantidade de aldeias ainda existente nos municípios do sertão maranhense. 
Os trabalhadores do rio Grajaú viviam cotidianamente sob tensão. Sem saber, eram torturados psicológica e fisicamente. Navegavam fazendo uso das mais rudimentares técnicas, partiam sem nenhum conhecimento prévio de onde iriam pernoitar, igualmente não tinham conhecimento de quando chegariam ao destino, não muito raro eram surpreendidos com a morte de algum companheiro, por tuberculose, malária ou "espetado" na ponta de uma vara, instrumento de trabalho e às vezes a causa mortis. Compartilhavam um espaço físico mínimo dentro das canoas onde as tensões explodiam e eram negociadas ou não. Nenhum espaço social é neutro, há disputas entre os indivíduos, oposições, solidariedade, compromisso, desobrigação. Esse minúsculo espaço vivido não impedia e, às vezes, as condições materiais obrigavam a união dos opostos (FRÉMONT, 1980, p. 36).

Quem são os vareiros do rio Grajaú? Quem são esses trabalhadores do rio? Na região estudada, no senso comum, caboclo é como o índio é normalmente chamado até hoje. Na baixada maranhense, o mesmo termo é utilizado para identificar qualquer pessoa do sexo masculino. Não há um estudo antropológico ou sociológico que defina a categoria desses homens que exerceram a profissão de vareiro nos rios do Maranhão. Não considero correto chamá-los caboclos, por ser uma denominação "genérica e de muitos significados em toda a Amazônia, mas cujo sentido primordial tende a indicar a origem rural do indivíduo" (SANTOS, 2003, p. 38). Largamente utilizado na Amazônia brasileira e quase sempre com sentido pejorativo, o termo caboclo é complexo e ambíguo. É normalmente usado na antropologia para diferenciar o típico camponês amazônico do imigrante vindo das mais diversas regiões do país. Tanto na fala coloquial quanto na acadêmica, é uma categoria de classificação social sempre feita por alguém que não tem o sentimento de pertencimento.

Um país de dimensões continentais como o nosso usou e usa diferentes termos regionais para identificar seus tipos humanos: sertanejo, para identificar de modo geral o nordestino que não habita o litoral; gaúcho, para toda a região sul do Brasil; caipira, para o habitante do interior de São Paulo que não reside no litoral; por sua vez, este último, o habitante do litoral, é denominado de caiçara; baiano, geralmente identifica todo nordestino, quando deveria identificar apenas aos nascidos no estado da Bahia. E há ainda vários outros tipos, como: potiguar, alencarino, timbira, dentre outros. Essa regionalização de tipos está intimamente ligada à geografia, às origens étnicas de cada população, aliadas à história de sua colonização, como afirma Lima (1999, p. 5). Podemos designá-los de "sertanejos amazônicos", como fez Carlos de Araújo Monteiro (apud TOCANTINS, 1999, p. 102), referindo-se aos nordestinos chegados à Amazônia expulsos pela monumental seca de 1877. Essa região, como quase todo o Maranhão, recebeu imensas levas de nordestinos.

Acredito que os vareiros do rio Grajaú possam ser comparados aos seus congêneres do rio São Francisco. Neves (1998, p. 116), que ao estudar o vale daquele rio, referindo-se aos trabalhadores embarcados, afirmou:

Os canoeiros já não eram homens que viviam apenas da coleta, caça e pesca, a exemplo dos seus ancestrais indígenas. Dentre suas atividades já se incluíam o plantio, a colheita e relações de troca (escambo), bem como a circulação monetária ainda que incipiente (NEVES, 1988).

Os vareiros do rio Grajaú, entre uma viagem e outra, "mantinham" uma roça em precárias condições cuja produção era apenas suficiente para a subsistência da família. A roça cuidada pela esposa e pelos filhos menores conseguia algo que só a necessidade ou a miséria explica, vendia da pequena produção o excedente. Produziam basicamente feijão, arroz, fava, mandioca e milho. A proteína animal era conseguida com a venda desses produtos. "Quando o patrão era bom, fazia um adiantamento antes do fim da viagem e dava pra gente ir passando", afirmou Libéria Capão ${ }^{1}$. Esses adiantamentos, sabe-se através das entrevistas, eram raríssimos.

\footnotetext{
${ }^{1}$ Libéria Capão, esposa de vareiro, idade ignorada, não sabe ler nem escrever e não lembra em que ano esses fatos ocorreram.
}

PACHÊCO FILHO, A.K.G.. "Empurrador de canoa não ganha nada não". Os vareiros do rio Grajaú e a circulação de 
O trabalho dos vareiros consistia em impulsionar embarcações saídas das oficinas do povoado Jaburu e adjacências. 0 transporte de produtos feito por canoas foi a única solução encontrada pelos comerciantes de Grajaú para suprir a falta de estradas e abastecer suas lojas e seus armazéns e, por conseguinte, a sociedade sertaneja em seu entorno. A cartografia do comércio não ficou restrita aos limites internos do Maranhão, atravessava a divisa natural e chegava ao norte de Goiás e ao sul do Pará. Abastecer esse imenso mercado com produtos transportados por canoas impulsionada por tração humana era praticamente desumano. Campos (1960, p. 334), em crônica sobre o trabalho dos vareiros do rio Parnaíba, assim se expressou: "o que caracteriza esse gênero de transporte primitivo é, todavia, a força que o aciona. Força humana. Braço de caboclo. Músculo de negro. Energia de homem branco embrutecido pela pobreza". Humberto de Campos não identificou a presença indígena tão comum nesse tipo de trabalho.

Esse ofício extenuante era exercido por doze, catorze e, às vezes, dezoito horas consecutivas, com um intervalo máximo de seis horas para descanso. Os vareiros eram contratados pelos donos de barco numa relação que parecia ser tipicamente capitalista. Recebiam a metade do salário nos últimos dias que antecediam a viagem, o restante seria pago ao término da jornada, o que raramente acontecia, pois o vareiro completava a viagem invariavelmente "devendo" ao patrão. Diferentemente de quem os explorava que vivia da acumulação, dos lucros provenientes dos fretes ou da venda de mercadorias. Muitos vareiros do rio Grajaú como afirmei antes eram índios.

Acham-se esses indígenas em um estado de civilização bastante adiantado, são sedentários e vestem-se como nosso homem do campo [...] e fornecem vareiros para os barcos que navegam o Alto Mearim e no Grajaú (JESUS, 1910, p. 18).

0 engenheiro Palhano de Jesus generalizou ao dizer que os indígenas viviam um "estado de civilização bastante adiantado" e usou um conceito de civilização, já aquela época, bastante ultrapassado. $\mathrm{O}$ homem branco é movido por outros códigos e dificilmente compreendia os valores indígenas, esses diariamente eram desrespeitados e transformados rapidamente em motivo de zombaria. Normalmente eram os últimos a fazerem as refeições, e sempre os mais exigidos. Os índios carregam, ainda hoje, o estereótipo de serem preguiçosos. Os homens "brancos" quase sempre usavam a barreira da língua a seu favor.

Os vareiros foram os responsáveis diretos pelo fortalecimento e desenvolvimento econômico da região. Viveram na mais completa ignorância de sua importância para o progresso material, do qual nunca lhes foi permitida a mínima participação, quer no sentido de melhoria das condições de trabalho, quer na aquisição de bens materiais que pudessem lhes proporcionar um mínimo de qualidade de vida. Trabalhavam sem nenhuma garantia social. 0 vareiro ou porco d'água teve sempre em sua companhia a "vara", seu principal instrumento de trabalho que o ajudava a se equilibrar nos pouco mais de vinte centímetros de largura da coxia de sua embarcação.

Campos (1960, p. 334) assim retratou o esforço dos vareiros:

Três, quatro de cada lado da barca, munidos cada um com uma vara que mede seis ou sete metros, e tão sólida que o peso é, já, suficiente carga para um homem, os vareiros vão, lentamente, passo a passo, um distante do outro, até a tolda da proa, e firmam a vara no fundo do rio fixam, em seguida, a parte superior, no músculo do peito acolchoado de carne calejada pela constância do exercício. E firmando-se aí, vergados para a frente, apoiados na vara, cuja maior parte mergulha na água, começam a caminhar vagarosamente, o passo medido, pela borda da barca, no rumo da popa.

Eles caminham para trás, como quem volta para o lugar de onde veio. A embarcação caminha para frente, avançando sempre. Cada passo que eles dão, regressando, a barca na ascensão pesada, rio acima, conquista outro, para adiante [...] Cada palmo de caminho fluvial vencido custa o esforço de seis ou oito peitos musculosos e nus, em que se fixam as varas, entrando pela carne (CAMPOS, 1960).

PACHÊCO FILHO, A.K.G.. "Empurrador de canoa não ganha nada não". Os vareiros do rio Grajaú e a circulação de 
Os passos dados em sincronia pelos vareiros caminhando em direção à popa com os pés descalços faziam um barulho rítmico, não havia e nem podia haver dissonância, quem os ouvia atentamente à distância, tinha certeza que eles haviam chegado de volta à proa, quando soava a última nota daquela "partitura musical", o som de "chuá" das longas varas de sete metros sendo lançadas novamente ao rio, reiniciando o ritmo de um dia inteiro de trabalho. Neco Brito (2008) disse-me que ainda lembra a letra e a melodia da música cantada pelos vareiros do rio Grajaú: "Olhei por cima do mato eu vi o sol se escondendo, já deu em cima da croa², meu Grajaú vem gemendo". O "gemido" ouvido e interpretado por Brito, como sendo lamúria, era o mais puro esforço físico feito por esses trabalhadores do rio.

Percorrendo lentamente, com passos cadenciados e precisos, a distância entre a proa e a popa sobre a borda da barca, os vareiros navegavam milhares de quilômetros fazendo sempre a mesma viagem - Grajaú a Vitória do Mearim, rio abaixo, ou Vitória do Mearim a Grajaú, rio acima -, transportando sempre as mesmas mercadorias, parando sempre nos mesmos portos. As peles de animais silvestres que transportavam faziam a canoa parecer "uma verdadeira arca de Noé" (CAMPOS, 1960, p. 335). Além das peles, transportavam couro de boi, babaçu, algodão, malva. Subindo o rio, rumo a Grajaú, transportavam pólvora, querosene, tecidos, cutelaria, remédios, louças - enfim, os mais variados tipos de produtos da "civilização", principalmente o sal. Entretanto, esses trabalhadores transportavam mais que produtos industrializados: carregavam sonhos, materializavam desejos, encurtavam distâncias. 0 mundo chegava à sociedade sertaneja trazido por suas mãos, através do rio Grajaú. Da cidade de Grajaú o mundo era "partilhado" e "conduzido" por tropeiros às regiões já mencionadas.

A jornada de trabalho desses homens tinha início ainda na madrugada, por volta das cinco horas, e se alongava até por volta das cinco da tarde. Em noites de lua cheia, excepcionalmente, quando a viagem estava muito atrasada por causa da estiagem, a marcha se estendia até mais ou menos nove horas da noite. Iniciavam o dia fazendo a principal refeição, cujo cardápio pouco variava e consistia quase sempre em arroz, fava, carne seca, toucinho e farinha. 0 menu usado pelos vareiros era preparado aproximadamente uns quinze dias antes do início da viagem. 0 dono da embarcação ou o "freteiro" providenciava a compra de carne correspondente a três bois que depois de abatidos eram desossados, retalhados e toda a carne era colocada em "varas de carne" sob o sol para serem "transformada" em carne de sol. Depois de seca, eram guardadas em caixas de madeiras que ficavam fechadas e a chave com o dono. 0 óleo usado para cozinhar era toucinho de porco, depois de salgado era depositado em gamelas e viajava sem nenhuma cobertura, ficava exposto à visitação dos insetos. José Maria Rodrigues, 81 anos, que foi passageiro em algumas dessas viagens, contou que:

[...] eles usavam fava, carne seca que eles traziam, eles chamavam frasqueiras, os grandes caixotes bem feitos que eles guardavam aquela carne, você podia até comer ela crua, sequinha que era gostosa. Era uma carne pretinha, carne de gado, aquilo eles traziam muito e toucinho. Outra frasqueira de toucinho e a fava, em grande quantidade que dava para ir e voltar, não tinha outra alimentação não. Às sete horas da noite a fava ia para o fogo, o tanto, de acordo com a tripulação, cozinhava a noite todinha, quando era de madrugada eles colocavam a carne e sete horas da manhã eles chamavam pro almoço, a gente almoçava (RODRIGUES, 2007).

Trabalhavam incessantemente até mais ou menos às duas horas da tarde, quando paravam para fazer a segunda refeição. Dessa feita, o cardápio era mais simples, conforme Rodrigues (2007): "Passava o dia, às duas horas da tarde eles paravam, pro chibé ${ }^{3}$. Aí parava, dava um pedaço de carne seca para cada um e farinha d'água. Eles usavam uma coitét, e nós que éramos passageiros

\footnotetext{
${ }^{2}$ Pronuncia-se crôa, cujo significado é banco de areia.

${ }^{3}$ Colocavam a água do rio dentro de uma cuia misturada com farinha de mandioca.

${ }^{4}$ Pequena cuia utilizada como recipiente para fazer refeições em algumas regiões do Maranhão.
}

PACHÊCO FILHO, A.K.G.. "Empurrador de canoa não ganha nada não”. Os vareiros do rio Grajaú e a circulação de 
levávamos o prato. E fazíamos aquele pirão d'água." O pedaço de carne do "lanche" vespertino nem sempre era entregue ao vareiro, o mais usual era eles receberem uma boa quantidade de farinha, depositada em suas respectivas cuias. Outra versão desse lanche nos foi contada por Cunha (2007):

Os vareiros faziam dois grandes cigarros, um de maconha e o outro de fumo de rolo. Fumavam intercalando os cigarros. Segundo eles, era para 'caldear'. Naquele tempo eles faziam isso para ter apetite para devorar um pirão de farinha, uma bacia cheia de farinha, metia dentro d'água, aquela palha subia, a corredeira tirava, então ficava só a farinha pura. Amarrava o barco debaixo de uma ingazeira. Aí preparavam um cigarro de fumo bruto e outro de maconha, eles iam puxando. Chamava-se 'galo de ar' um e outro, uma pitada de um, uma pitada do outro. Aí os bichos velhos ficavam com os olhos miudinhos assim... Aí eles passavam, escolhiam um ou dois quilos de babaçu, que vinha na carga, lavavam direitinho, aí se passava pra comer babaçu e farinha molhada, então nesse intervalo de oito horas até as cinco da tarde eles faziam esse lanche (CUNHA, 2007).

Sem saber, os vareiros usavam a expressão "caldear", que dentre outros significados que dizer: "revigorar, robustecer." (HOUAISS, 2008, 148). Enquanto "lanchavam", o dono da embarcação fazia a escolha dos possíveis locais do pernoite, fazia várias simulações, pois não havia certeza de chegarem ao local desejado. Quase sempre o ponto de pernoite era determinado pela proximidade do fim do dia. Iniciavam os preparativos para o albergamento. Era então servida a terceira e última refeição do dia, a "Maria Isabel" ${ }^{5}$ a qual fiz referência antes. Esse menu era servido invariavelmente todos os dias enquanto durasse a viagem, sessenta, noventa dias, subindo o rio Grajaú. A duração da viagem estava sempre vinculada à profundidade do rio: quanto mais profundo o rio, menos tempo, mas sempre muito trabalho. No período da estiagem, o leito do rio ficava muito seco, a pouca água deixava as itaipavas à mostra. Isso exigia dos vareiros muito mais esforço físico e experiência profissional. Para conseguirem vencer as corredeiras, que se tornavam quase intransponíveis, várias técnicas eram utilizadas a subida no gancho. Esses mecanismos eram usados sempre no trecho Vitória do Mearim / Grajaú). Rodrigues (2007) relata:

Nesse tempo não tinha desmatamento e o rio Grajaú era estreito e muito arborizado quase que as árvores cobriam todo o rio, fazia uma espécie de túnel. Eles tiravam aqueles ganchos de madeira, aí ficavam pegando na rampa para vencer as corredeiras. E puxavam no gancho até passar o trecho mais difícil (RODRIGUES, 2007).

Quando aliviavam as corredeiras e finalmente elas eram vencidas, a embarcação voltava a ser impulsionada por varas. Essa prática geralmente demorava um dia todo de muito esforço. Outra atividade feita pelos vareiros nesse processo de levar as canoas com suas respectivas mercadorias rio acima era chamada de espia. Tal operação consistia em prender uma corda numa das pontas à proa da embarcação e passar a outra extremida de por uma árvore previamente preparada, que tinha seu tronco descascado para se tornar liso e ajudar a corda a deslizar mais facilmente. Feito isso, exceto o piloto que ficava no comando do leme, todos os vareiros puxavam a corda de uma só vez, fazendo força por igual.

Essa ação era repetida quantas vezes se fizessem necessário para deslocar uma canoa encalhada. A insistente repetição desse movimento fazia a embarcação ir avançando lentamente, metro a metro, até vencer a corredeira. Quando o período da estiagem se prolongava e os relevos submersos do rio emergiam, essas operações aqui relatadas quase nada resolviam. Fazia-se necessário, então, retirar certa quantidade da carga embarcada e transportá-la no ombro dos vareiros para uma distância segura, adiante da corredeira. Com o barco mais leve, era possível vencer o obstáculo. Conduzia-se então o barco até aonde havia sido transportada a carga, que era reembarcada. Havia viagens em que essa operação era feita mais de cinco vezes.

Cunha (2010) foi proprietário de lancha e trabalhou vários anos navegando no rio Grajaú, fazendo

\footnotetext{
5 “Maria Isabel” é arroz cozinhado com pedaços de carne cortada medindo os pedaços entre um e dois centímetros. Prato muito comum no Nordeste brasileiro.
}

PACHÊCO FILHO, A.K.G.. "Empurrador de canoa não ganha nada não". Os vareiros do rio Grajaú e a circulação de 
escambo. As mercadorias que levava no barco, café, açúcar, remédios, etc. eram trocadas por produtos agrícolas, principalmente algodão e arroz. Em um ano que não conseguiu lembrar, o verão foi terrível, os barcos demoraram tanto a subir o rio que começou a faltar produtos industrializados em Grajaú, contou-me:

Naqueles verões bem puxados, o rio secava e ficava só com uma lâmina bem fininha d'água, quando a gente ia subindo com a canoa carregada, a gente passava de dez a quinze dias lá cavando com prato, fazendo parede de esteira de palha de babaçu pra água focar só ali para ir abrindo os canais para poder avançar a viagem (CUNHA, 2010).

As paredes de palha entrelaçadas como se fosse um corredor, funcionava como uma eclusa. Entretanto a mais comum, e o que ocorria invariavelmente todos os anos, era o leito do rio ser literalmente aberto com instrumentos utilizados na agricultura: enxadas ou enxadecos ${ }^{6}$, no rio Grajaú, eram utilizadas como equipamentos náuticos. "Às vezes a gente passava um dia todinho para andar cem metros, quando andava" (ALVES, 2008).

Além de todo o esforço físico despendido pelos vareiros ao longo do dia e da reposição das energias feita através de uma alimentação rústica e pouco diversificada, concorria para o mais completo desconforto desses homens durante o período diurno a profusão de mosquitos chamados de cabo verde ${ }^{7}$.

Era um besourinho bem pequeno, azul. Esse todo mundo tinha medo, porque onde ele picava mais parecia uma furada. Doía e coçava e virava um calombo e dali virava uma ferida. E dá coceira, o sujeito coçava com a unha virava logo uma ferida (RODRIGUES, 2007).

Era impossível para os vareiros arremessarem as varas ao rio conforme já foi aqui narrado e impedirem a picada do cabo verde ou de outro inseto não menos atemorizador chamado pium, que ao picar deixava a pele das pessoas "bordadinha de vermelhão, parecia assim uma pontinha de sangue. Coçava demais e abria ferida em algumas pessoas" (RODRIGUES, 2007). Se para os passageiros, que podiam se proteger dos insetos, as dificuldades, aliadas à monotonia da viagem, eram quase insuportáveis, os vareiros não sofriam com resignação: tinham que recorrer ao consumo de maconha. Martins $(2005)^{8}$, referindo-se ao uso do entorpecente pelos vareiros, afirmou: "Eu comprava oitenta quilos de diamba para uma viagem de ida e volta".

Ao final da tarde, quando chegavam ao local previamente escolhido para o pernoite, o que nem sempre era possível, principalmente nos meses de estio, quando as viagens se tornavam totalmente imprevisíveis. Durante o jantar, todos opinavam sobre a melhor estratégia que deveria ser utilizada para seguirem viagem e torná-la mais proveitosa no dia seguinte, ao mesmo tempo em que avaliavam as dificuldades enfrentadas e vencidas naquele dia. À proporção que ia escurecendo, "o cabo verde 'entregava' os vareiros às muriçocas", segundo Alves (2008), vareiro de uma única viagem. Era também o momento que o dono do barco ou "freteiro" usava para "curar" sua tripulação. As águas do rio Grajaú contêm uma alga que, após um longo contato da pele com a água, como é o caso dos vareiros, causa feridas entre os dedos chamadas de frieiras, além de profundas rachaduras nos calcanhares. Tais ferimentos eram tratados à noite, com azeite de castanhas de caju fervido, fornecido pelo freteiro, com o objetivo de recuperar o mais rápido possível a sua mão de obra. "Passava um insope $^{9}$ nas curuba ${ }^{10}$ e quando o dia raiava começava tudo de novo"11 — afirmou Alves (2008). Essa

\footnotetext{
${ }^{6}$ Instrumento de ferro que é a metade de uma enxada.

${ }^{7}$ A cor do mosquito é azul, mas à luz do sol fica com uma tonalidade parecida com a cor verde.

${ }^{8}$ MARTINS, Deodato. Deodato Martins. Depoimento (2005, 2008, 2009). Grajaú - MA, AKGPF, 5p.

${ }^{9}$ Algo parecido com as hastes flexíveis (cotonetes) de hoje, usado para espalhar o azeite fervendo nas feridas.

${ }^{10}$ Ferimento.

${ }^{11}$ José Camilo, idade ignorada, entrevista concedida ao autor em 30 de setembro de 2006.
} 
foi a medicina empregada por anos no tratamento das feridas d'água, como eram conhecidas.

Durante a noite, mesmo com pouca água no rio, recomendava a prudência que a canoa devia ser amarrada, e assim era feito. Após o tratamento das afecções, tinha início para todos, passageiros e vareiros, uma verdadeira batalha contra os pernilongos. Para evitar tamanho desconforto, fazia-se de tudo, alguns passageiros utilizavam peles de animais curtidas.

Nessas viagens meu pai me dava um couro de bode curtido para colocar no fundo da rede e proteger as costas, porque o pano da rede não resistia às furadas dos pernilongos, das mutucas, dos piuns (RODRIGUES, 2007).

Os vareiros, após o término daquela verdadeira sessão de tortura a que eram submetidos com o azeite de castanha fervendo sendo pingado nas feridas, fumavam grandes e grossos cigarros de maconha. 0 cansaço físico de uma intensa jornada com mais de doze horas de trabalho, aliado ao poder entorpecente da maconha, fazia-os dormir com a "epiderme anestesiada", indiferentes aos ataques de todos os impertinentes insetos que pululavam às margens do rio Grajaú.

Sobre as condições desumanas em que os vareiros pernoitavam, José Maria Rodrigues (2007) relatou:

Eles dormiam em cima do convés, aquela parte que fica na frente da embarcação. Eles dormiam e aquilo ali para eles não valia nada. Roncavam! Eles ficavam de lado e colocavam uma coité12 sobre o 'pé do ouvido' para impedir a entrada de água, se chovesse (RODRIGUES, 2007).

Continuando o depoimento, nosso entrevistado disse: "Eles ficavam tão cansados de trabalho que quando batia dormia de qualquer jeito, dormia tudo assim que nem porco" (RODRIGUES, 2007). As memórias de Rodrigues sobre essas viagens são de um jovem filho de fabricante de sapatos, com uma condição financeira infinitamente melhor que a dos vareiros, recorda ainda horrorizado o que presenciou. Passados mais de sessenta e cinco anos, Rodrigues (2007) reconhece o embrutecimento dos homens provocado pelas condições de trabalho: "Esse pessoal era maltratado, era um trabalho cruel, trabalho escravo daqueles que se pode considerar escravidão, só suportavam porque eram viciados na maconha". Os "freteiros" e os donos de barco, pelo que consegui pesquisar, incentivavam deliberadamente o consumo da Cannabis sativa, pois sabiam não haver outro modo de alguém suportar tais condições de trabalho.

O uso cotidiano e indiscriminado da maconha durante anos inegavelmente viciava os vareiros. Ao desembarcarem nas cidades, a abstinência imposta pela repressão policial para o uso do alucinógeno os obrigava ao consumo exagerado de bebidas alcoólicas: São João da Barra, vinhos baratos (o mais comum era o da marca Moscatel). Entretanto, o que eles mais bebiam era basicamente aguardente de cana, pura ou "temperada" com as mais diversas misturas: casca de laranja, cravinho, casca de jatobá, erva-cidreira. Havia ainda outras que eram com misturas mais exóticas e serviam para "fechar o corpo" ou "arranjar mulher". Durante o período em que as embarcações ficavam atracadas aguardando serem carregadas, ou enquanto eram descarregadas, eles ficavam bebendo.

Em Vitória do Mearim, a estada mínima dos vareiros era de oito dias, tempo suficiente para fazer alguns reparos na embarcação e às vezes o proprietário aumentar o estoque de mantimentos. Para os vareiros, esse era um período de total ociosidade. Durante essas "férias", segundo nos afirmou Rodrigues (2007):

O que eles ganhavam era só pra beber, eram doidos por álcool. Acho que devido à vida que levavam. A hora que chegavam aqui eles pegavam e bebiam, mas não mexiam com ninguém. Bebiam e se embriagavam pelas canoas (RODRIGUES, 2007).

\footnotetext{
${ }^{12}$ Coité, expressão utilizada para identificar o depósito feito com a metade de uma cabaça.
} 
José Rodrigues não conseguiu se lembrar das inúmeras contendas nas quais os vareiros se envolviam na zona do porto e do meretrício em Vitória do Mearim. Os "baianos," como eram chamados os vareiros de Grajaú pelos habitantes da Baixada maranhense, não eram vistos como pessoas de bom grado, mas como "homens sem formação e sem respeito por coisa alguma, saíam às ruas de Vitória como verdadeiros vândalos" (COELHO, 2004, p. 3). Havia, na sociedade, um grande preconceito para com esses trabalhadores, em sua grande maioria, negros e índios. Oficialmente, a escravidão tinha acabado havia pouco mais de meio século, de modo que a maioria branca não estava acostumada a ver negros livres circulando pelas ruas. Bêbados, então... não eram aceitos numa sociedade predominantemente escravocrata. A tensão entre negros vareiros e brancos urbanos era permanente, os primeiros querendo extravasar na bebida e nos prostíbulos das cidades por onde navegavam o infortúnio de serem vareiros; já os segundos tentando contê-los dentro dos limites impostos pelos Códigos de Postura. Esses trabalhadores não eram desordeiros, como entendia parte da sociedade "ordeira" e branca. Eram isto sim, embrutecidos pelas condições adversas em que viviam cotidianamente na luta pela sobrevivência.

Os inúmeros conflitos nos quais costumeiramente os vareiros se envolviam em Grajaú e Vitória do Mearim, principalmente no ambiente mais frequentado por eles, os respectivos cabarés: Retombo, em Grajaú e no "Sôa", e Banha, em Vitória surgiam quase sempre de assuntos banais e eram motivados pela ingestão excessiva de álcool. Não havia uma razão preponderante. Embriagados, brigavam por namoradas imaginárias que nunca tiveram e exigiam fidelidade de quem fizera de sua profissão exatamente a licenciosidade. Outro tema bastante recorrente nas discussões era qual cidade seria a melhor: a Grajaú sertaneja dos "baianos" ou a Vitória dos "quiribas"? Embora não tenha estudado especificamente o vareiro, o geógrafo Lopes (1970, p. 195) classificou os tipos regionais maranhenses, afirmando ser 0 :

[...] Sertanejo do Chapadão ambicioso e rude. Este diverge profundamente dos outros, conserva-se indiferente, como produto lídimo da elaboração étnica interior, cujo impulso principal veio do São Francisco, do Sul (LOPES, 1970).

Lopes faz referência aos primeiros povoadores de colonização que chegaram à região, vindos da Bahia e de Pernambuco, na segunda metade do século XVII. Não há dúvida que o homem sertanejo é totalmente diferente do homem do litoral. Nos costumes, na linguagem, na alimentação, no modo de vestir-se etc. Ser "ambicioso e rude" não é uma característica específica de quem é sertanejo, pode ser de qualquer ser humano indiferentemente de onde tenha nascido.

A análise feita por Lopes (1970, p. 195), sobre os tipos maranhenses é extremamente preconceituosa. Para o autor de Uma Região Tropical, o "pescador ribeirinho, indolente, reflexo quase fiel do selvagem; o vaqueiro dos campos baixos, mais empreendedor, aventuroso". Essa tipologia também não cabe a esses habitantes da Baixada maranhense. Raimundo Lopes nomeia os tipos regionais maranhenses sem, entretanto, mencionar os critérios utilizados para tal tipologia. Entendendo que ele mesmo se contradiz quando afirma:

É-nos difícil apreender e fixar o caráter psicotécnico maranhense com precisão [...] em primeiro lugar, estamos diante de um tipo mais vago e mais complexo; depois esses 'retratos' coletivos exigem um vigor de julgamento e de traços que são o apanágio de tudo quanto sai de estilos excepcionais como o do artista de 0s sertões (LOPES, 1970, p. 195).

Donde concluo ser a tipologia utilizada pelo geógrafo equivocada. Esses trabalhadores do rio discutiam, brigavam, matavam e morriam pela tensão proporcionada pelo trabalho. Usavam os alcaloides e a maconha como fuga da miséria em que viviam desde a mais tenra idade. Eram analfabetos e "embrutecidos pela pobreza". Simples e rústicos, foram sempre dependentes e humilhados, ora pela cor da pele, ora pela etnia à qual pertenciam. Raríssimas vezes eram tratados e considerados como seres humanos. Poucas eram as vezes que não estavam sob efeito de alucinógenos durante as viagens, nem para dormir ficavam sóbrios. 
Os vareiros do rio Grajaú, contrariando o escritor russo, não eram "infelizes cada um à sua maneira" (TOLSTÓI, 1973, p. 9). Eles carregavam consigo a mísera sorte de terem nascidos próximo do rio ou de terem "desaguado" ainda na juventude nesse mesmo rio, de onde a grande maioria nunca mais saiu. Os que conseguiam uma aposentadoria na velhice, aqueles que envelheceram, moravam afastados dos centros urbanos e quase sempre habitavam literalmente "na beira do rio". Passavam o dia tecendo tarrafas, fumando maconha e repetindo inúmeras vezes suas histórias de viagens e da vida desdita.

O trabalho em si já era um castigo físico, conforme já foi aqui relatado. Entretanto, alguns freteiros trabalhavam armados e chegavam a castigar fisicamente os vareiros com chicote feito de relho $\mathrm{cru}^{13}$, caso se recusasse a trabalhar por doença ou cansaço, evidenciando uma clara relação de coerção das liberdades individuais e de domínio que os proprietários de barcos exerciam sobre os seus trabalhadores. "tinha uns vareiros do Martinho Guabiraba eram dois irmãos, Zezão e Domingão. Eram uns pretos altos, eram propriedade dele e ele não abria porque tinha força tinha resistência" (CUNHA, 2010).

São bastante conhecidas, em Grajaú, histórias de maus tratos dispensados aos vareiros pelo proprietário de barco Nati Guabiraba. Segundo a versão conhecida, numa das viagens VitóriaGrajaú, um vareiro fugiu à noite, depois de ter apanhado do seu patrão. Tão logo o dia raiou, Nati Guabiraba alcançou o povoado mais próximo à margem do rio. Comprou um cavalo de cela e passou o restante do dia procurando o fugitivo. Encontrou-o ao final da tarde escondido numa roça de mandioca. Apontando o revólver para ele, subjugou-o, amarrou-o e o trouxe de volta à canoa.

Quando um ou dois fugiam para um povoado qualquer, eles paravam a canoa e o patrão pegava o rifle, botava nas costas e ia atrás. Quando encontrava botava pra trabalhar até... (RODRIGUES, 2007).

Essa expressão "trabalhava até" se afigura carregada de simbologia. 0 vareiro fujão caía em desgraça não só com o patrão, mas com seus companheiros também:

[...] Ficava vigiado e tinha que trabalhar até pagar o que devia. Eles nunca tinham lucro, todo tempo era devendo. Quando eles faziam uma viagem já chegavam lá devendo, aí eles tinham que vir pagar esse débito (RODRIGUES, 2007).

Ou seja, era uma dívida eterna e impagável. Esse episódio exemplifica bem que a autoridade do "freteiro" ou proprietário de barco jamais podia ser contestado. Não impor ordem poderia gerar desobediência evoluir para um motim, foi a explicação mais comum que ouvi.

Outro episódio do qual o mesmo freteiro é o principal protagonista me foi contado em entrevista pelo índio Virgulino Guajajara ${ }^{14}$, índio de etnia Tenetehara-guajajara. Nosso narrador foi um dos inúmeros índios que trabalharam como vareiros no rio Grajaú. Segundo ele, após trinta e oito viagens ininterruptas, resolveu parar, pois já se sentia com "as forças fracas" e já não tinha "disposição alguma para trabalhar na roça e vivia cansado". Ao comunicar sua decisão para Nati Guabiraba, com quem trabalhava havia mais de vinte anos, o "freteiro" não concordou e imediatamente lhe apresentou um "rosário de contas que eu devia pra ele".

Essa situação era muito comum entre os vareiros de Grajaú. 0 nível de degradação havia atingido índices altíssimos. A penúria causada pelos parcos salários, "empurrador de canoa não ganhava nada não, era 200, 100, 50 mil réis." (GUAJAJARA, D., 2010). Aliada ao vício etílico e de entorpecentes,

\footnotetext{
${ }^{13}$ Relho cru, couro de boi seco ao sol após 15 dias de secagem.

${ }^{14}$ Virgulino Guajajara, já falecido, concedeu-me entrevista em janeiro de 2008, quando tinha 86 anos de idade. Havia sofrido dois Acidentes Vasculares Cerebrais (AVC), sofria de pressão arterial alta e se locomovia numa cadeira de rodas. Atribuía seus males às precárias condições de trabalho quando vareiro.
} 
deixava-os submissos aos freteiros e proprietários de embarcação, devido às pesadas dívidas que lhes eram impostas. Os vareiros nunca tinham nenhum saldo credor junto aos seus empregadores. O mesmo Guajajara, D. (2010) nos contou que suas esposas "iam na rua pedir dinheiro ao patrão para comprar comida e eles nunca davam. Aí mulher nossa ia vender lenha pra arranjar algum dinheiro pra dar comida aos curumim".

A relação entre esses trabalhadores do rio e seus patrões foi sempre muito tensa: todos trabalhavam no limite de suas capacidades físicas e psicológicas. As viagens eram planejadas para serem cumpridas entre trinta e cinco e quarenta e cinco dias; contudo isso nunca ocorreu. Na prática, as viagens demoravam em média noventa dias. Há relato de uma, no verão de 1915, que durou seis meses. 0 não cumprimento dos prazos para o dono da embarcação significava prejuízo, mais que isso, a possibilidade de começar a faltar alimentação, passava a ser real, o nível de tensão aumentava. Homens trabalhando diariamente até a exaustão, sem previsão da chegada, era extremamente perigoso.

O episódio da saída de Virgulino Guajajara do serviço de vareiro virou caso de polícia. Inconformado com a perda do trabalhador, Nati Guabiraba apresentou queixa ao delegado Benício Duarte, exigindo receber o débito contraído pelo índio vareiro. Caso contrário, exigia sua imediata prisão, para que servisse de exemplo a outros que por desventura tivessem a mesma ideia. Para solucionar o caso em definitivo, o delegado não prendeu o índio e pagou sua "dívida" para com o reclamante. Virgulino Guajajara tinha adquirido sem querer uma dívida de gratidão para com o delegado. Mas que isso, precisava agora pagar o dinheiro que nunca devera, ao freteiro nem ao delegado:

Saí da delegacia pensando como ia fazer para pagar o delegado. Fui matutando, aí me lembrei que eu criava porco e, quando cheguei na aldeia Morro Branco, juntei seis dos maior que eu pensei que dava pra pagar o dinheiro (GUAJAJARA, V., 2008).

Virgulino conseguiu deixar de ser vareiro graças à generosidade do delegado Benício Duarte, que se recusou a receber os porcos em pagamento. Não estando de acordo com a atitude do delegado, Virgulino Guajajara vendeu os porcos e voltou à delegacia com o dinheiro, para pagar sua conta e o delegado continuou se recusando a receber a dívida que o índio não havia contraído nem com ele nem com seu antigo patrão.

Ainda não foi contabilizada - e provavelmente nunca o será - a quantidade de vareiros mortos, índios ou não, na faina do rio Grajaú. Muitos morreram de malária ou "impaludismo", como essa moléstia é conhecida no senso comum. Outros tantos - e não poucos - morreram de tuberculose, doença que, na década de trinta do século passado, foi quase uma epidemia em Grajaú: "Começava a viagem bonzim e quando vinha voltando morria" (GUAJAJARA, V., 2008). Alguns trabalhadores do rio morriam picados por cobras, principalmente no trecho do rio conhecido como "Regô". Outros morreram com a vara literalmente espetada no peito durante o trabalho. Esse tipo de acidente não era comum, mas acontecia. A vara ficava presa em algumas pedras no fundo do rio e o vareiro, por um momento de desatenção, não conseguia erguer a ponta da vara fundeada. Com a outra extremidade colocada em seu peito, ao mudar o passo, o barco ia para frente, ele ficava espetado, abraçado à vara para sempre...

Quando os acidentes fatais aconteciam no verão, os vareiros eram enterrados nas margens do rio, com todos os seus pertences, que geralmente eram quase nada - um calção, duas camisas, uma rede, um lençol de chita bastante desbotado, uma coité que lhe serviu a refeição, uma colher e um copo, que, quando era novo havia sido esmaltado. No inverno, quando as águas se espraiavam, cobrindo as margens do rio, o enterro se tornava difícil, pois era preciso navegar muito até encontrar terra firme. (CUNHA, 2007). Narrou que em determinada viagem, um índio morreu.

E agora como nós vamos enterrar esse índio? Aqui nós não podemos. A terra está daqui a não sei quantos quilômetros ninguém pode ir. Uma intempérie danada. Nós vamos enterrar. Enrolaram o índio na rede, fizeram um pavio e foram cavar assim numa croa com um prato. A água com quatro dedos por cima né, uma barreira mais alta que tinha,

PACHÊCO FILHO, A.K.G.. "Empurrador de canoa não ganha nada não". Os vareiros do rio Grajaú e a circulação de 
e cavando, cavando e ia caindo pra dentro da vala até que conseguiram e jogaram o índio lá e a água passou a camada de areia muito fina por cima dele, foi enterrado lá. (CUNHA, 2007).

Muitos vareiros ficaram enterrados nas "margens" do rio Grajaú, esses tiveram mais sorte. Quando não havia uma croa por perto, os enterros eram feitos em árvores como a gameleira. 0 dono do barco, em comum acordo com os demais vareiros, enrolava o morto em sua rede, fazia o "pavio" e procurava os galhos mais altos de uma gameleira. Amarravam a rede e o seu dono de forma horizontal, após algumas preces em voz baixa e individuais, seguiam a viagem todos calados e imaginando: "o próximo pode ser eu". Quando voltavam de Vitória, encontravam os urubus nas gameleiras onde havia sido amarrado o morto. Alves (2008), referindo-se a seus companheiros que eram sepultados às margens do rio Grajaú, diz que todas as vezes que passavam os vareiros passavam pelo local onde os companheiros haviam sido supostamente enterrados, gritavam: “Vamo beber cachaça e ir pro Retombo ${ }^{15}$ lá no Grajaú!???!!!”.

A rodovia Belém - Brasília inaugurada ainda no governo JK foi uma das principais causas do fim da navegação no vale do rio Grajaú. Evidentemente que essa navegação um dia iria acabar, mas a BR-010 antecipou os fatos.

Sálvio Dino, escritor e articulista do jornal 0 Estado do Maranhão, em sua coluna semanal, publicou em 25 de junho de 2002, um artigo no qual analisava e comemorava o asfaltamento da BR 226 que passa por Grajaú.

[...] Agora, o governador José Reinaldo vem de inaugurar oficialmente a tão sonhada rodovia 226 - ligando em menor espaço de tempo e com maior economia de combustível o velho Grajaú à capital do estado e ao Planalto Central. Chegou em termos de comunicação rodoviária moderna, o que tanto queríamos. Pois bem. Em tão importante data (recordo emocionado os sentidos apelos que eu fazia da tribuna da Assembléía Legislativa clamando pelo asfaltamento dessa estrada de integração, autêntica alavanca desenvolvimentista dos nossos vales verdes, povoados de gente laboriosa e riquezas precisando de boas vias de escoamento) sinto que se deve prestar justa e merecida homenagem aos heróicos pioneiros da comunicação grajauense: o inesquecível e bravo vareiro. Nunca será tarde dizer-se alto e a bom som: o desenvolvimento do Porto da Chapada (fundado em 1811), deveu-se à navegação do seu rio. Através deste pôde Grajaú transformar-se no principal empório comercial da região centro-sul do estado. Houve época em que Caxias e Grajaú no Império foram as duas maiores cidades do interior maranhense portanto, meu abraço afetuoso a todos os descendentes dos destemidos navegadores da ribeira grajauense. Que tal a idéia de levantar-se um monumento ao vareiro grajauense! Pense na idéia, minha cara prefeita Bernadete. [grifo meu]. (Jornal OEMA, São Luís, 25 de junho de 2002, Caderno Alternativo, p. 6).

Dino recomenda à prefeita a construção de um monumento, que pudesse ser o elo entre a identidade social e a memória. A memória só pode emergir de um grupo que ela une como diz Halbwachs (2006), há tantas memórias quantos grupos existentes. Ela é, por natureza, múltipla, coletiva e individual. Quer o articulista a construção da memória erigida em pedra e cal como a petrificação de "um lugar da memória" como se o esquecimento "fosse uma vergonha" e não uma parte dessa mesma memória.

Como preservar a memória dessa atividade profissional, que tanto contribuiu para o desenvolvimento do sul do Maranhão e mesmo para a criação de um mercado regional com os estados vizinhos, se hoje ela não é 'útil' para a atual sociedade? Erguendo um monumento? Acredito que não. Não compreende o articulista que os Vareiros do rio Grajaú pertencem à história e não mais à memória. A própria solicitação da construção de um monumento é uma demonstração inequívoca

\footnotetext{
${ }^{15}$ Nome do cabaré que ficava no Porto das Pedras, bairro de Grajaú, bem próximo do rio e que era muito frequentado pelos vareiros.
}

PACHÊCO FILHO, A.K.G.. "Empurrador de canoa não ganha nada não". Os vareiros do rio Grajaú e a circulação de 
de que a memória encontra-se prisioneira da história e como disse (NORA, 1993, p. 7) "fala-se memória precisamente porque ela não existe mais".

A navegação com fins mercantis no rio Grajaú cessou definitivamente no final da década de 1970 . As sofridas, mas alegres viagens nas canoas empurradas à vara por meses a fio pelos trabalhadores do rio, os vareiros, só restam resquícios de lembranças. Esses fragmentos foram colhidos nos depoimentos de nossos entrevistados. 0 índio Damião Guajajara, 92. Luiz Arruda, 82. José Maria Rodrigues, 87. Neco Brito, 87. Dico Barros, 88. Wilson Assunção, 85, Edivalso Silva, 70. Darci Mendonça, 79. Hilton Mendonça, 78. José Camilo e Libéria Capão, idades ignoradas. Alguns morreram durante nossa pesquisa: Deodato Martins, Virgulino Guajajara, Hiran Guará. Estes depoimentos foram a base para o estudo da navegação do rio Grajaú.

\section{Conclusão}

O Maranhão possui uma das maiores bacias hidrográficas do Brasil. No entanto, o estudo dos rios e da navegação, notadamente o rio Grajaú, a despeito de sua importância socioeconômica para o sertão do Maranhão e norte de Goiás, nunca foi objeto de análise. Diante de tal constatação, considero este que estudo dará uma contribuição para se começar a reverter esse quadro, na medida em que foi analisada a importância do rio para a região do Alto Grajaú. Partindo da compreensão do rio como centro irradiador da dinâmica ocupacional e comercial foi possível analisar a cidade de Grajaú como o lugar para onde convergiram as ações dos trabalhadores do rio. Assim, neste ensaio foi privilegiado o olhar sobre os indivíduos pelo rio e pela cidade, na defesa do território e exploração do rio, a dinâmica comercial do rio e da cidade e a memória dos trabalhadores do rio, também denominados, vareiros.

A análise da ação dos indivíduos no rio e na cidade de Grajaú permitiu uma compreensão de que o rio exerceu um papel fulcral no desenvolvimento das atividades socioeconômicas da região do Alto Grajaú. A intensa navegação entre o rio Mearim, na cidade de Vitória, e o rio Grajaú promoveu a circulação de produtos no sul do Maranhão, no atual Estado do Tocantins e no sul do Pará. A cidade de Grajaú passou a ser o centro receptor e distribuidor de importantes produtos, tais como o sal, remédios, tecidos, facas, pólvoras, chumbos, entre outros, vindos de São Luís, capital do Estado.

Contudo, as águas do rio Grajaú não transportaram somente produtos. Como agente de ligação, o rio carregou um dos principais personagens dessa circulação, os vareiros. Esses trabalhadores do rio, além de empurrarem embarcações com varas, cheias de mercadorias, ora a favor ora contra a correnteza do rio, compartilharam experiências em dois ambientes muito distintos: o litoral e o sertão. Sob o sol escaldante ou chuvas torrenciais ou, em raras noites de luar, o labor extenuante desses trabalhadores somente era entrecortado por gemidos produzidos pelos esforços empreendidos no empurrar das embarcações, pelos impactos das varas na água a cada novo movimento, ou ainda pelas necessárias tragadas de um cigarro de "diamba" ao final do dia. Guardiães da memória do rio, esses indivíduos levaram uma vida ritmada pela navegação. Foram o combustível que impulsionou as embarcações e protagonistas de uma história esquecida, agora trazida a público sob a forma de fragmentos de memórias.

A discussão a respeito da vida que brota do rio proposta por este ensaio permite também uma reavaliação do papel exercido pela navegação no desenvolvimento das regiões do sertão maranhense, durante uma época em que o rio foi a principal via de ligação entre o norte e o sul do Estado. A importância crescente da navegação incrementou as atividades comerciais, o modo de vida de parcela da sociedade sertaneja e a dinâmica fluvial no centro sul maranhense.

Assim, este ensaio conclui afirmando que a navegação entre os rios Grajaú e Mearim impulsionou a vida sertaneja por meio de diversas atividades comerciais com produtos como, por exemplo, o sal, que atendia desde as necessidades básicas do cotidiano sertanejo, até as atividades pecuárias, destinadas ao comércio exportador. Complementando esse cenário em que rio, cidade e sertão compõem a mesma paisagem, os vareiros foram os grandes agentes dinamizadores da vida nesses ambientes. 


\section{Referências}

ALVES, José Camilo. Depoimento (2008). Grajaú - MA, AKGPF, 8p.

BRAUDEL, Fernand. 0 mediterrâneo e o mundo mediterrânico. Rio de Janeiro: Martin Fontes, 1983.

BRAUDEL, Fernand. Civilização material, economia e capitalismo, séculos XV-XVIII. Rio de Janeiro: Martins Fontes, 1998. v. 2: Os Jogos das Trocas.

BRITO, Manoel Maciel. Depoimento (2007). Grajaú [MA]: AKGPF, 13p.

CAMPOS, Humberto de. Memórias inacabadas. São Paulo: Gráfica e Editora Brasileira Ltda. 1960.

COELHO, Arimatea. Os barqueiros do rio Grajaú. Folha da AVL. Órgão da Academia Arariense-Vitoriense de Letras - AVL, ano IV, n. 13. Arari/Vitória do Mearim [Maranhão] - abril de 2004.

CUNHA, Wilson Assunção. Depoimento (2007/2009/2010/2011). Grajaú [MA]: AKGPF, 53p.

DINO, Sálvio. Jornal OEMA, São Luís, 25 de junho de 2002, Caderno Alternativo p.6.

FÈBVRE, Lucien. 0 Reno: história, mitos e realidades. Tradução de Eliana Aguiar. Rio de Janeiro: Civilização Brasileira, 2000.

FRÉMONT, Arman. A região, espaço vivido. Coimbra: Livraria Almedina, 1980.

GUAJAJARA, Damião. Depoimento (2010). Grajaú-MA, AKGPF, 5p.

HALBWACHS, Maurice. A memória coletiva. Tradução de Beatriz Sidou. São Paulo: Centauro Editora, 2006.

HOUAISS, Antônio. Dicionário Houaiss: sinônimos e antônimos. Instituto Houaiss; diretor do projeto Mauro Salles Villar. 2. ed. São Paulo: Publifolha, 2008.

JESUS, José Palhano de. Relatório do Reconhecimento ligeiro da Estrada de Ferro do Itapecuru ao Tocantins. São Luís: Imprensa Oficial, 1910.

LIMA, Deborah de Magalhães. A Construção histórica do termo caboclo: Sobre estruturas e representações sociais no meio rural amazônico. Novos Cadernos NAEA vol.2, no 2 dez 1999, p, 6. Disponível em: http://repositorio.ufpa.br/jspui/bitstream/2011/3125/1/Artigo_ConstrucaoHistoricaTermo.pdf

LOPES, Raimundo. Uma região tropical. Rio de Janeiro: Cia. Editora Fon-Fon e Seleta: 1970.

NEVES, Zanoni. Navegantes da integração: os remeiros do rio São Francisco. Belo Horizonte: UFMG, 1998.

NORA, Pierre. Entre memória e história: A permanência dos lugares. Tradução de Yara Aun Khoury. São Paulo: Projeto História, PUC-S, dezembro de 1993.

OEMA [Jornal], São Luís, 25 de junho de 2002, Caderno Alternativo, p. 6.

OLIVEIRA, Maria de Fátima. Portos do sertão: cidades ribeirinhas do rio Tocantins. Goiânia: Editora da PUC Goiás, 2010.

PACHÊCO FILHO, Alan Kardec Gomes. Francisco de Paula Ribeiro e a conquista do território sul do Maranhão. In: As Novas Geografias dos Países de Língua Portuguesa: Paisagens, Territórios, Políticas no Brasil e em Portugal. Coordenação: CUNHA, Lúcio; PASSOS, Messias Modesto dos; JACINTO, Rui. Edição: Centro de Estudos Ibéricos, Guarda - Portugal, 2010. 
SANTOS, Fernando Sérgio Dumas dos. Os caboclos das Águas Pretas: saúde, ambiente e trabalho no século XX. 2003. 276 f. Tese (Doutorado em História) - Instituto de Filosofia e Ciências Humanas da Unicamp, Campinas [SP], 2003.

TOCANTINS, Leandro. Os historiadores e os rios: natureza e ruína na Amazônia brasileira. Brasília: Paralelo 15, Ed. Universidade de Brasília, 1999.

TOLSTÓI, Leão. Ana Karenina. Tradução de João Gaspar Simões. São Paulo: Circulo do Livro S/A, 1973.

\subsection{Entrevistas}

Alan Kardec Gomes Pachêco — Grajaú [MA].

Darci Mendonça - Vitória do Mearim [MA].

Deodato Martins - Grajaú [MA].

José Camilo - Grajaú [MA].

Edivalson Silva - Grajaú [MA].

José Rodrigues - Vitória do Mearim [MA].

Libéria Lima Sousa (Libéria Capão) — Grajaú [MA].

Luiz Alves de Arruda — Grajaú [MA].

Neco Brito - Vitória do Mearim [MA].

Virgulino Guajajara — Grajaú [MA].

Wilson Assunção Cunha - São Luís [MA]. 